\title{
RIDING THE SECOND WAVE OF VENTURE FUNDING
}

\section{SAN FRANCISCO-The second} wave of venture capital support for start-up biotechnology companies is now rolling in, according to Brook $\mathrm{H}$. Byers of Kleiner Perkins Caufield \& Byers, located here. The new companies are focusing on specific application areas, he says, using the firstgeneration technologies as tools. Byers spoke at Online International's (New York, NY) "Biotech San Francisco" conference, which attracted some 650 registrants in November.

The first wave of venture financing lasted from the early '70s until 1984, says Byers. Never funding more than one biotech company a year during this time, Byers' firm provided seed capital for some current household names (depending, of course, on the nature of the household): Genentech, Collagen, Hybritech, Applied Biosystems, The Liposome Company, and Gen-Probe. Then, from 1984 until 1986, most of the venture capital firms "caught their breath," he says. But 1986 has seen Kleiner Perkins put seed money into no fewer than four biotech start-ups:

- Athena (San Francisco, CA), spe- cializing in diagnostics and therapeutics for neural disorders like Alzheimer's disease;

- Insite Vision (San Francisco, CA), which will use novel technology to deliver ophthalmic drugs to the eye;

- Gensia (San Diego, CA), formed around an undisclosed chemistry technology whose first application will be for a prophylactic cardiovascular drug; and

- Idec (San Diego, CA), which in September acquired and merged with the Biotherapy Systems (Palo Alto, CA) unit of Damon Biotech (Needham Heights, MA). The firm is testing anti-idiotype monoclonal antibodies against $\mathbf{B}$-cell lymphoma in three hospitals; later the company hopes to use anti-idiotypes as vaccines.

"There are a tremendous number of opportunities for new biotechnology companies," Byers stresses. Some of these include therapeutics against viruses, continuous-process manufacturing equipment, new lymphokines, computer-aided drug design, drug delivery, and dermatologic applications. "Biotechnology investments require creativity on the part of the venture capitalist," he adds. "When you read a business plan you've got to be thinking not just what it says but what it doesn't say and what it should say." Also, new biotech companies tend to arrive at the venture capitalist's doorstep at an earlier stage than do their oft-cited brethren in the computer industry. "Learning how to manage the scientist is the most important thing a start-up venture capitalist can learn," he says.

Byers has been acting as president of both Idec and Insite Vision, but he hopes soon to be able to step asideprobably by gleaning a shining star or two from the ranks of the more mature biotech concerns. "I didn't want to be president of two companies simultaneously," Byers stresses. And once relieved of his day-to-day responsibilities, the financier will have more time to do what he likes best: start novel biotech companies. Even though Kleiner Perkins is yet to have a failure in biotechnology, Byers is quick to quote one of his firm's mottos: "If you live by the crystal ball, then you'd better acquire a taste for ground glass." - Arthur Klausner

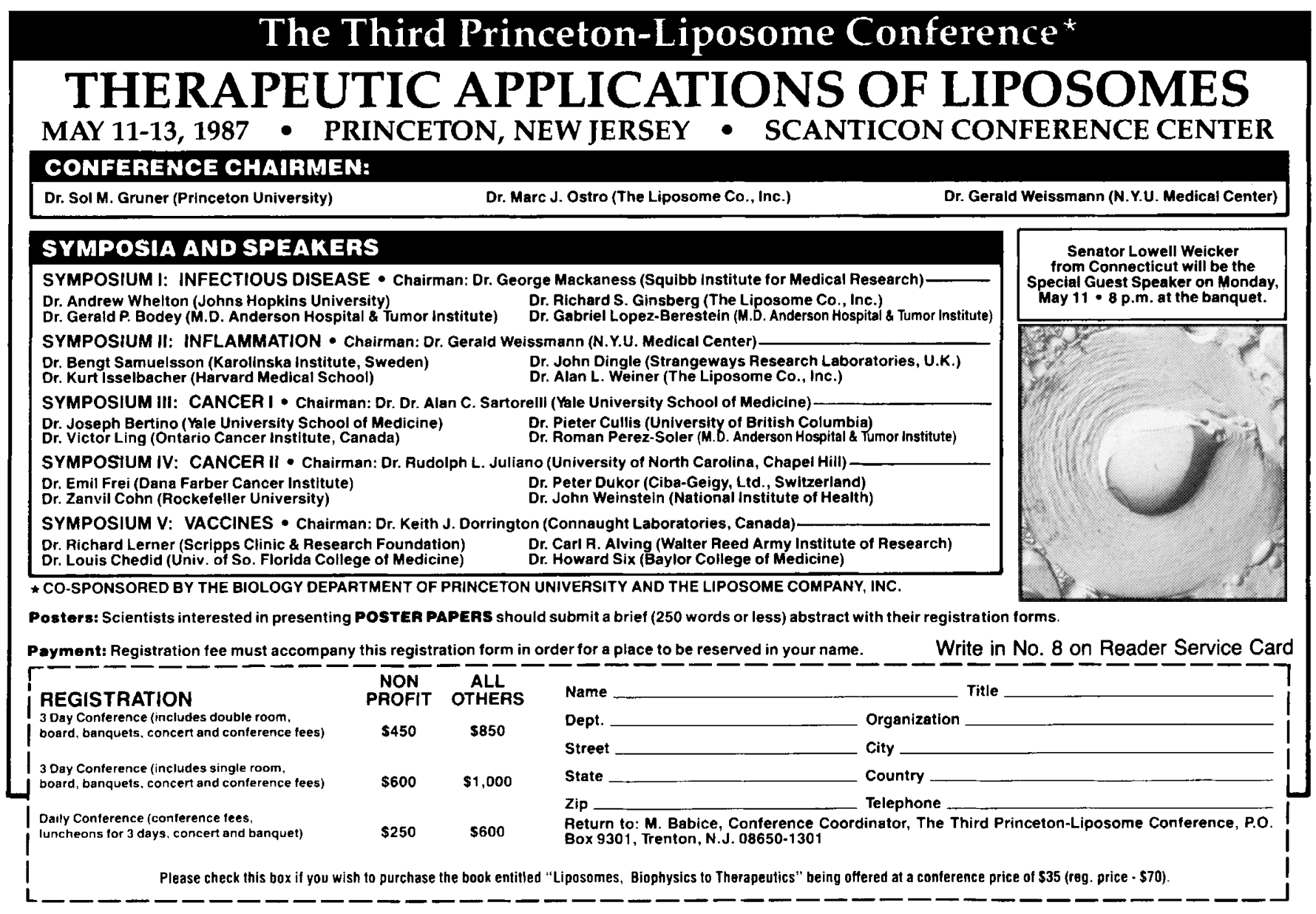

